\title{
Networks and network strategies: New theorization based upon a systematic literature review
}

\section{Rossella Canestrino ${ }^{1}$ (D), Amir Forouharfar ${ }^{2}$}

\begin{abstract}
PURPOSE: This paper aims to introduce a general all-embracing taxonomy of networks and its relevant strategies to facilitate the teaching and learning of the strategic concepts of networks in strategic management. METHODOLOGY: To fulfill its intention, the paper has adopted a systematic literature review (SLR), since the introduced taxonomy and its corresponding strategies should be a compendious reflection and summary of the current literature of the studies on strategic networks. RESULTS: The paper unfolded seven potential configurations of the networks and then proceeded with the proposition of their relevant strategies with regard to the networks' relationships and forms. These networks were named as Reciprocally Interdependent Networks, Sequentially Interdependent Networks, Partnering Networks, Complementary (Overlapping) Networks, Supporting (Logistic) Networks, Distributing Networks, and Co-Innovation Knowledge-Sharing Networks. Their corresponding network strategies were identified as Multi-Level Promotion Strategy, Just-In-Time Strategy, Network Partnership Strategy, Compensatory Strategy, Network Logistic Strategy, Distributing Network Strategy, and Network R\&D Strategy, respectively. IMPLICATIONS FOR THEORY AND PRACTICE: Systematics or a system of classification is a fundamental necessity in any field of knowledge, benefiting both academia and learners. Accordingly, this paper provides a comprehensive but concise means of classifying networks and their strategies to overcome the paucity still existing in the literature. These efforts invite future research and conversation about networks and network strategies, proposing a guiding framework for the debate. ORIGINALITY AND VALUE: Lack of consensus about theories and conceptualizations in strategic network studies became an inspiration for this research, which allowed for the clarification of the mentioned existing paucity.
\end{abstract}

1 Rossella Canestrino, Ph.D., Assistant Professor, Department of Management and Quantitative Studies, Parthenope University of Naples, Via Generale Parisi 13, 80132 Naples, Italy, email: rossella.canestrino@uniparthenope.it (ORCID ID: https://orcid.org/0000-0003-2629-867X).

2 Amir Forouharfar, Ph.D., University of Sistan and Baluchestan, Iran, email: amir.forouharfar@gmail.com (ORCID ID: https://orcid.org/0000-0002-9962-3544). 
Keywords: network taxonomy, network configuration, network strategy, strategic management, systematic literature review (SLR)

\section{INTRODUCTION}

Global networks in commerce, business, communication, R\&D, goods and passenger transportation - which are the fruits of gigantic and massive-scale economic globalization - have culminated in a modern global economy, which is inherently a network economy. Thus, as Carmichael (2016) puts it, "As our economy has grown more global and more digital, businesses have had to shift their competitive strategies, marketing techniques, and business models. One of the most powerful changes? The rise of network effects." Globalization has come hand in hand with the global networks and hence strategic studies of these networks in the organizational world could equip the organizational strategists with the necessary insight, not only for taking advantage of the emerging, current or nascent opportunities, but also for avoiding the potential strategic threats out there. From an academic perspective, a network is certainly not a new topic and previous efforts have been made to introduce conceptual clarity (Blanco et al., 2011; Isett et al., 2011; Berry et al., 2004; Börzel, 1998): disciplines addressing networks include health sciences, management, political science, social science, social work, computer science, ecology, etc. (Hill, 2002). An extensive literature dealing with the analysis of inter-organizational relations and networks within the management field (Mizruchi \& Galaskiewicz, 1993; Jarillo, 1993; Ebers \& Jarillo, 1998; Sydow, 1998) embeds its roots in organization theory.

Moreover, Oliver and Ebers (1998) performed a literature search culminating in a network analysis of 158 articles published in four leading journals from 1980 to 1996. According to their research, the most frequently employed theories within this field are resource dependence, political power, and network approach. However, the proliferation of different perspectives resulting in the creation of various concepts, definitions, and metrics is responsible for a confusing picture requiring further clarifications (Dal Molin \& Masella, 2016). Thus, the current and severe paucity of consensus-making theories and conceptualizations in strategic network studies is the rationale for such a study. One of the primary reasons for such conceptually systemmaking meagerness could be the network approach, as roughly a new emerging paradigm in strategic management. Context and relations play pivotal roles in this approach. It strongly relates to the organizational environment and it consists of various concepts from the firms' internationalization to the inter-organizational connections. Despite the mentioned considerations, 
network approaches still lack a sound typology for the strategic networks, thus requiring new advancements in the field. The need for such a typology relates to the growing importance of network economy in the truly global organizations day in day out. Thus, this paper's aim is to introduce a general all-embracing taxonomy of networks and its relevant strategies to facilitate the teaching and learning of strategic concepts of networks within a system in strategic management. This process paves the way for reaching an answer to the following research question $(R Q)$ :

$R Q$ : What is the literature-supported taxonomy of inter-organizational networks and its relevant network strategies?

Hence, one of the approaches to presenting a typology for the strategic networks is by discovering the strategic networks' configurations in the real inter-organizational world. The logic behind such an approach is the possibility of arranging the salient strategic elements of any network through the outstanding and influential relationships and by their directions. These two features, which could be defined as structuration (i.e., finding and presenting justifiable structures in the studied networks) and directionality (i.e., finding the relationship directions within each network), contribute to the schematic presentation of the network configurations.

Additionally, even though strategic researchers of networks have reached praiseworthy results, current mainstream strategic literature on networks suffers deep one-sidedness. In other words, the current literature mainly deals with one or at most very limited aspects of networks and strategies. This one-dimensional approach to the strategic study of networks is currently a ubiquitous and prevalent phenomenon easily diagnosable in highly-cited works of scholarly quality, for example from the 'industrial organization (IO) perspectives' in McIntyre and Srinivasan (2017) to 'strategic alliances' in Kale, Singh, and Perlmutter (2000).

Yet, broadly, introducing strategic network typology could be either deductive or inductive. Induction or inference from a general principle is out of the question, since due to the vast and stupendous arena of strategic networks it is nearly impossible to propose a universal general theory. Thus, the only approach for fulfilling the research goal is by applying induction or inference from particulars. The particulars in our study are the secondary data derived out of the precise systematic strategic networks' literature study.

On the other hand, the organizational morphologies were labeled under broad categories as network, network-centric, networking or networked organizations and in the management literature each shed light on a specific 
dimension of the concept of network, but inwardly. In other words, they mainly refer to the internal networks within organizations, which are irrelevant when referring to the network approaches developed in the organizational/ strategic studies.

In this paper, first in the methodology section, our SLR, its criteria and steps were unfolded. After that, both descriptive and content analyses were performed and the network literature was reviewed and analyzed here. Finally, according to our research results, seven network configurations, as well as their relevant strategies were proposed in line with the studied literature.

\section{METHODOLOGY}

In the context of networks and their strategy, the Systematic Literature Review (SLR) may be considered an effective and robust way to collect, sum up and evaluate evidence, since an SLR is usually undertaken to deeper understanding into the phenomenon being addressed within existing studies, as well as to provide recommendations for further research (Unterkalmsteiner et al., 2012). For this review, the authors have broadly followed the guidelines proposed by Kitchenham and Charters (2007). These guidelines have established that a review should be comprised of three phases, including its planning, conducting, and reporting. In line with the mentioned guidelines, the research questions should be first stated and then some relevant criteria be developed for collecting the literature. Particularly, two main phases (deskbased literature study and literature compilation) were managed at this stage. In the next step, a plan for classifying, describing, and coding the literature was developed through literature filtration and variables' distillation. As a final step, the literature was synthesized (Forouharfar et al., 2019; Merli et al., 2018; Denyer \& Tranfield, 2009; Tranfield et al., 2003) in order to provide a taxonomy for networks and their corresponding strategies (Table 1).

Scopus and Web of Science (WoS) were selected as sources of data because they were deemed to be the most comprehensive and authoritative scientific catalogs (Merli et al., 2018), featuring full texts and searchable cited references for top journals, as well as providing complete information in the field of networks and firms' strategy. Many scholars (Bakkalbasi et al., 2006; Burnham, 2006; LaGuardia, 2005; Dess et al., 2006; Li et al., 2010) have compared the coverage, features and citation analysis capabilities of Scopus and WoS, concluding that these two databases are permanently improving their potentiality. Depending on the above, the use of both Scopus and WoS is in line with the research question in this paper. 
Table 1. Systematic approach in reviewing strategic networks' literature in this study

\begin{tabular}{|c|c|c|c|c|}
\hline \multicolumn{5}{|c|}{ LITERATURE REVIEW } \\
\hline \multirow[t]{2}{*}{ Method } & \multirow[t]{2}{*}{ Context } & \multicolumn{2}{|r|}{ Process } & \multirow[t]{2}{*}{ Final Results } \\
\hline & & a. Phase & b. Purpose & \\
\hline \multirow{5}{*}{$\begin{array}{l}\text { Systematic } \\
\text { Literature } \\
\text { Review } \\
\text { (SLR) }\end{array}$} & $\begin{array}{l}\text { Strategic } \\
\text { Networks }\end{array}$ & $\begin{array}{l}\text { \# 1: Desk-Based } \\
\text { Literature Study }\end{array}$ & $\begin{array}{l}\text { Acquisition of } \\
\text { secondary data }\end{array}$ & \multirow{5}{*}{$\begin{array}{l}\text { Salient variables/ } \\
\text { elements for } \\
\text { classifying strategic } \\
\text { networks } \\
\text { and introducing } \\
\text { their corresponding } \\
\text { schematic } \\
\text { configurations }\end{array}$} \\
\hline & & $\begin{array}{l}\text { \# 2: Literature } \\
\text { Compilation }\end{array}$ & $\begin{array}{l}\text { Compilation of strategic } \\
\text { network literature }\end{array}$ & \\
\hline & & $\begin{array}{l}\text { \# 3: Literature } \\
\text { Filtration }\end{array}$ & $\begin{array}{l}\text { Filtration of the } \\
\text { literature variables/ } \\
\text { elements based on } \\
\text { their relevance to } \\
\text { strategic networks }\end{array}$ & \\
\hline & & $\begin{array}{l}\text { \# 4:Variables' } \\
\text { Distillation }\end{array}$ & $\begin{array}{l}\text { Extraction of the } \\
\text { strategic as well as } \\
\text { network variables/ } \\
\text { elements }\end{array}$ & \\
\hline & & $\begin{array}{l}\text { \# 5:Variables' } \\
\text { Generalization }\end{array}$ & $\begin{array}{l}\text { Generalization of the } \\
\text { extracted variables/ } \\
\text { elements of strategic } \\
\text { networks }\end{array}$ & \\
\hline
\end{tabular}

Thus, after reading several publications on the general network topic (e.g., Håkansson \& Laage-Hellman, 1984; Jarillo, 1988; Hinterhuber \& Levin, 1994; Borch \& Arthur, 1995; Ibarra, Kilduff, \& Tsai, 2005; Knoben, Oerlemans, \& Rutten, 2006; Hite, 2008; Chang, Chiang, \& Pai, 2012; Krzakiewicz \& Cyfert, 2013; Kohtamäki, Thorgren, \& Wincent, 2016; Christakis et al., 2020), and based on the authors' experience, five keywords were selected as search strings employed in both databases, namely:

1) Strategic network.

2) Strategic network configuration/shape/type/typology.

3) Network strategy.

4) Network strategy element/variable/feature.

5) Organizational network configuration/shape/type/typology.

Depending on the selected keywords, the following research string was defined in accordance with Boolean and proximity operators suggested narrowing down the scope of advanced search:

("Strategic network*" OR "organizational network*") AND

(configuration* OR shape* OR type*) OR ("Network strategy*") AND (element* OR variable* OR feature*) 


$$
\begin{gathered}
\text { AND NOT } \\
\begin{array}{c}
\text { "Internal network*" OR "strategic coalition*" OR "organizational } \\
\text { relationship*" }
\end{array}
\end{gathered}
$$

According to the databases' research functionalities, the chosen keywords were searched in "Topic" (covering Title, Author Keywords, Abstract, Keyword Plus ${ }^{\circledR}$ ) on WoS, as well as in "Title, Author Keywords, Abstract" on Scopus. As recommended in the literature, only journal articles were selected, which inherently improves a literature review's potential rigor and quality (Vigolo et al., 2018; Orzes et al., 2018; Jia \& Jiang, 2018). Since most academic journals are English based, with English being the most used language by researchers in the modern global academic community (Snyder et al., 2016), the research only focused on the English papers.

After defining the language and the type of the papers, articles belonging to Business, Management, and Accounting; as well as Economics, Finance and Social Science subject areas were considered in our databases' search. Moreover, no chronological restriction was employed. As a result, WoS returned 149 papers and Scopus 42 papers, giving a total of 191 documents. Table 2 summarized the research strategy adopted to develop the systematic literature review.

Additional exclusion criteria were also adopted for the systematic review, as suggested by De-La-Torre-Ugarte-Guanilo et al. (2011), when rejecting papers referring to:

1) Internal organizational networks.

2) Internal strategic coalitions.

3) Internal organizational relationships.

After the removal of redundant duplications, a final sample of 172 papers remained (77 full papers and 95 abstracts $^{3}$ ).

\footnotetext{
3 The distinction between full papers and abstracts depends on the availability of the documents on the selected databases. Since the key strategic characteristics and variables were important to us for moulding the network strategic figures and we could easily find these key variables in some of the relevant papers' abstracts, both full papers and abstracts were considered in managing our analysis.
} 
Table 2. Summary of the results for the employed search string

\begin{tabular}{|c|c|c|c|c|}
\hline Search string & Scopus & $\begin{array}{l}\text { Total sample } \\
\text { size on Scopus }\end{array}$ & WoS & $\begin{array}{l}\text { Total } \\
\text { sample size } \\
\text { on WoS }\end{array}$ \\
\hline $\begin{array}{l}\text { ("strategic network*” } \\
\text { OR “organizational } \\
\text { network*”) AND } \\
\text { (configuration* OR } \\
\text { shape* OR type*) OR } \\
\text { ("network strategy*") } \\
\text { AND (element* } \\
\text { OR variable* OR } \\
\text { feature*) }\end{array}$ & & 77 & & 409 \\
\hline AND NOT & & & & \\
\hline $\begin{array}{l}\text { "internal network*" } \\
\text { OR "strategic } \\
\text { coalition*" OR } \\
\text { "organizational } \\
\text { relationship*" }\end{array}$ & & & & \\
\hline \multicolumn{5}{|l|}{ LIMITED TO: } \\
\hline Language & English & 75 & English & 391 \\
\hline Document type & Articles & 54 & Articles & 298 \\
\hline Subject Areas & $\begin{array}{l}\text { - Business/ } \\
\text { Management } \\
\text { and Accounting } \\
\text { - Economic, } \\
\text { Econometric and } \\
\text { Finance } \\
\text { - Decision Science } \\
\text { - Social Science } \\
\text { - Multidisciplinary }\end{array}$ & 42 & $\begin{array}{l}\text { - Management } \\
\text { - Business } \\
\text { - Economics } \\
\text { - Social Science } \\
\text { Interdisciplinary } \\
\text { - Multidisciplinary } \\
\text { Science } \\
\text { - Business Finance } \\
\text { - Operation } \\
\text { Research } \\
\text { Management } \\
\text { Science }\end{array}$ & 149 \\
\hline
\end{tabular}

\section{LITERATURE REVIEW FINDINGS}

\section{Descriptive analysis}

Following Siva et al. (2016), the year of publication, type of paper, adopted methodology, etc. was established as our analytical categories (Table 3). 
Table 3. Our research analytical categories

\begin{tabular}{ll}
\hline Category & Description \\
\hline Year & Year in which the paper was published \\
Country & Countries where authors have published research \\
Journal & Journals in which authors have published research \\
Type of paper & $\begin{array}{l}\text { Type of paper (empirical paper, conceptual paper, } \\
\text { literature review) } \\
\text { Adopted methodology }\end{array}$ \\
& $\begin{array}{l}\text { Methodology adopted to manage the research } \\
\text { (qualitative, quantitative, mixed methods) }\end{array}$ \\
\hline
\end{tabular}

Table 4 shows the number of publications published from 1983 to 2021. Our latest access for searching on Scopus and WoS was on March 18, 2021. This means that potentially some of the publications for the last year (2020) were still under review or publishing by their pertinent journals. Hence, the incorporated data in this research, about the papers published in 2021, should be considered provisional and are expected to increase until the end of the year. In order to evaluate and fully understand the possible trends, we divided the whole period by four, investigating them through a content analysis.

Table 4. Number of papers published from 1983 to 2021

\begin{tabular}{ll}
\hline Period of time & No. of publications \\
\hline $\begin{array}{l}\text { First Period } \\
\text { (1983-1992) }\end{array}$ & 5 \\
\hline $\begin{array}{l}\text { Second Period } \\
\text { (1993-2002) }\end{array}$ & 14 \\
\hline $\begin{array}{l}\text { Third Period } \\
\text { (2003-2012) }\end{array}$ & 53 \\
\hline $\begin{array}{l}\text { Fourth Period } \\
\text { (2013-2021) }\end{array}$ & 100 \\
\hline Total & $\mathbf{1 7 2}$ \\
\hline
\end{tabular}

The first paper about the topic was published in 1983. During the first period (1983-1992), papers mainly belong to the social science subject areas, aiming to explore the role of inter-organizational networks and the way they support formulation of policy, democratization, as well as urban development. However, the papers roughly doubled in the second period. It has only been since the beginning of 2011 that scholars started focusing on inter-organizational networks from the managerial and strategic perspectives. The papers published during the third period (2003-2012) are diverse, as no specific network issue seems to prevail over the others. By contrast, 
a predominant approach/method was emerging for the analyses, with several scholars providing conceptual frameworks of networks and network analysis. The final period (2013-2021) shows a significant growth in the number of the strategic network papers to 100 in total, representing an increase of almost 50\% in comparison to the previous period (2003-2012). In the fourth period, concepts such as "innovation," "innovation process," "businessmodel innovation," "innovation systems," and "organizational learning" were largely emphasized when discussing firms' networks and strategies, mainly with the intention of exploring the linkage between stakeholders' interactions and the firms' potentiality for success. As scholars emphasize (Biemans, 1991; Håkansson \& Waluszewski, 2007; Powell, Koput, \& SmithDoerr, 1996; Rampersad, Quester, \& Troshani, 2010), firms' competitiveness in contemporary markets increasingly requires co-operation within extensive networks, as many technological innovations tend to require multi-sectoral collaboration. Researchers have acknowledged that while the involvement and participation of diverse stakeholders in the innovation process are essential, they complicate interaction. Therefore, examining inter-organizational networks and interactions as strategic management issues becomes crucial when discussing the network-participating firms' relationships.

Moreover, according to the country analysis, pertinent articles from 42 different countries from five continents - Africa, America, Asia, Europe, and Oceania - were identified. The USA (38 contributions) and the UK (24 contributions) represent the highest number of published papers (nearly $36 \%$ of all the studied papers).

Table 5 shows countries with the highest contribution in the research field. The ranking is limited to the top 15 countries, since the number of publications under 5 was not considered.

Europe (other than the UK) is the continent with the largest participation with 67 articles (38.9\%) from 9 different countries (Germany, Netherlands, France, Italy, Finland, Denmark, Poland, Romania, Spain), where Germany produced 16 articles, as the highest contributing country to the strategic networking literature. 
Table 5. Countries with the highest contribution in the field

\begin{tabular}{llll}
\hline Ranking & Country & No. of publications & $\begin{array}{l}\text { Contribution to the field } \\
\text { (\% on the whole sample) }\end{array}$ \\
\hline 1 & USA & 38 & 22 \\
2 & UK & 24 & 13.9 \\
3 & Germany & 16 & 9.3 \\
4 & China & 12 & 6.9 \\
5 & Australia & 11 & 6.4 \\
6 & Canada & 9 & 5.2 \\
7 & Netherlands & 9 & 5.2 \\
8 & France & 8 & 4.6 \\
9 & Italy & 8 & 4.6 \\
10 & Finland & 6 & 3.4 \\
11 & Denmark & 5 & 2.9 \\
12 & Poland & 5 & 2.9 \\
13 & Romania & 5 & 2.9 \\
14 & Russia & 5 & 2.9 \\
15 & Spain & 5 & 2.9 \\
\hline
\end{tabular}

The 172 selected papers come from 126 different journals from within very diverse fields, nevertheless pertinent to management and management studies, thus revealing a significant fragmentation and dissonance in strategic network literature. For example, 53 papers, out of the studied papers, were published in 33 diverse journals, but only in few circumstances; the studied journals accepted more than 4 papers dealing with relevant or the same topics on strategy and networks.

Table 6 shows the list of journals that have published the study sample of articles from 1983 and 2021. Journals with fewer than five papers were not included, as their number of publications was considered irrelevant. Information about the Impact Factor (IF), and SCImago ranking were collected from the journals' official websites, as well as from SCImago's ranking system. The IF provides scholars with an objective measure of the importance of different journals within a given category (Rey-Marti et al., 2016). In addition, $\mathrm{SClmago}$ is a prestige metrics based on the idea that not all citations are the same. It provides a quantitative and qualitative measure of the Journal's impact, based on a similar algorithm to Google page ranking. 
Table 6. Journals publishing the articles

\begin{tabular}{|c|c|c|c|c|c|}
\hline Ranking & Journals & Publisher & $\begin{array}{l}\text { No. of } \\
\text { publications }\end{array}$ & $\begin{array}{l}\text { Impact } \\
\text { factor } \\
\text { (IF)* }\end{array}$ & $\begin{array}{l}\text { Scimago } \\
\text { journal } \\
\text { rank } \\
(\mathrm{SJR})^{* *}\end{array}$ \\
\hline 1 & $\begin{array}{l}\text { Industrial Marketing } \\
\text { Management }\end{array}$ & Elsevier & 9 & 4.695 & 125 \\
\hline 2 & $\begin{array}{l}\text { Journal of Business and } \\
\text { Industrial Marketing }\end{array}$ & Emerald & 7 & 2.497 & 62 \\
\hline 3 & $\begin{array}{l}\text { Strategic Management } \\
\text { Journal }\end{array}$ & $\begin{array}{l}\text { John } \\
\text { Wiley and } \\
\text { Sons Ltd }\end{array}$ & 6 & 5.463 & 269 \\
\hline 4 & $\begin{array}{l}\text { Journal of Business } \\
\text { Research }\end{array}$ & Elsevier & 4 & 4.874 & 179 \\
\hline 5 & $\begin{array}{l}\text { Technological Forecasting } \\
\text { and Social Change }\end{array}$ & Elsevier & 4 & 5.846 & 103 \\
\hline
\end{tabular}

Our study reveals the need for improving the quality of contributions in the field of networks, since only 30 papers (in the studies sample) were listed among the top 5 high-ranked journals, with the Strategic Management Journal hosting 6 of them.

In order to provide a full understanding of the selected papers, they were finally categorized according to the article type (i.e., empirical, conceptual, review) and the applied methodology, namely qualitative versus quantitative. The results showed that the majority of the reviewed contributions were empirical studies (62\%), followed by conceptual papers $(30.63 \%)$ and reviews (7.37\%). From a methodological perspective, $34.6 \%$ of the empirical studies adopted qualitative approaches, $57.1 \%$ adopted quantitative approaches, and only $8.3 \%$ used a mixed-method approach (combining both qualitative and quantitative methodologies).

\section{Thematic analysis}

According to our literature review, three main issues were outstanding:

First, "The term 'network' is often misconstrued" (Satell, 2015; p. 1). In any organization, we could have two types of networks: (1) internal networks and (2) inter-organizational networks. The network approach deals with the second type of networks - the networks that constitute the surrounding environment. 
Second, any study of organizational networks is a contextual phenomenon. That is strictly relevant to the context such as organizational structure, environment, relationship, or inter-synergism. Particularly, Satell (2015) referred to a network as an organizational structure, stating "... networks are informal structures. If it can fit on a traditional org chart, it's not a network." Moreover, he continues, "For functional purposes, networks have two salient characteristics: clustering and path length. Clustering refers to the degree to which a network is made up of tightly knit groups while path length is a measure of distance - the average number of links separating any two nodes in the network." There is not a unanimously/commonly accepted or developed definition for these organizations (Krzakiewicz \& Cyfert, 2013); but, "A 'network organization' is usually conceived as an organization that is quick and flexible in adapting to changes in its environment" and hence they are adaptable and have a special organizational structure (Vega-Redondo, 2013, p. 72) for the facilitation of inter-organizational/inter-company cooperation. Yet, in network approaches, we search for the constituting elements of the sophisticatedly inter-organizational interwoven networks, which are replete with idiosyncratic motifs and incentives for their involvement and participation in the networks. In other words, setting aside the common tendency of network organizations for adaptability and environmental cooperation, they all share another common salient feature, which is the undeniable strategic propensity for synergistic inter-organizational connections and even network generation and later network sophistication. Besides, two main phenomena, fostering the emergence of the concept, were the nonstop globalization and the necessity for inter-organizational connection, cooperation, competition and, in many cases, rivalry.

According to Krzakiewicz and Cyfert (2013), the rising relevance of international business cooperation, especially in the 1960s, called for the exploration of inter-organizational solutions. The emerging globalized markets and the ever-growing necessity for outsourcing required new organizational designs and structure. Thus, 'hollow corporation' and 'modular organization' have soon become established as two of the most familiar network organizational designs. Particularly, the introduction of the "hollow corporation" in the 1980s could be interpreted as one of the earliest signs of emphasizing inter-organizational solutions and approaches. 'Hollow corporations' "focus on their core competencies and outsource peripheral processes" and 'modular organizations' "order different parts [modules] from internal or external providers and assemble them [the product modules] into a product" (Narasimhan \& Yu 2021, p.1); they act for "the vertical disaggregation of the firm [structural modules] and the use of market mechanisms within hierarchies" (Kuntz \& Vera, 2007, p. 48). 
Although outsourcing and its benefits were not the only strategic necessity for accentuating the need for designing organizations with the emphasized tendency towards inter-organizational networking and interrelationmakings, it played one of the major roles for the justification of the trend. The ever-increasing contracting out of manufacturing and services providing jobs needed precisely defined networks. Thus, inter-organizational networks were not only limited to nongovernmental entities, but they also extended to the governments' execution of their departmental affairs and public service provision through contractors. For example, only by $1980,80 \%$ of the people involved in implementing the United States departments' programs and plans were contractors (Crawford \& Krahn, 1998).

Third, as discussed above, networks could be found either within organizations (in network organizations) or outside of the organizations (in the organizational environment). The strategic network approach mainly focuses on the organizational environment, its emergence, texture, and sophistication.

To address the specific theme of this paper, namely strategic networks and their configurations, we should not neglect that theoretical arenas as diverse as embedding, dependence on resources, social capital and industrial networks have been studied. As Lin et al. (2011, p. 183) report, "researchers have realized the crucial impact of embeddedness on governance structures of strategic alliances." Based on the data from strategic alliances among semiconductor firms in Taiwan, the authors also revealed the influential significance of 'network structural embeddedness' on 'the design of alliance governance' among the companies within the network. Network embeddedness is not only crucial for knowledge sharing but also for the innovation and development of enterprises (Liu \& Tang, 2020; Canestrino \& Magliocca, 2019). In addition, network relationships among organizations could lead to resource dependence and even external control by the outside constituting organizations within the network. For example, a study by Mitchell (2014) on the strategic responses to resource dependence among transnational NGOs registered in the United States, demonstrated that these organizations engagement in fundraising activities to support their operations globally led to their excessive dependence on the external environment for financial support and hence resource dependence which could culminate in external control. Additionally, corporate social capital, "as processes of forming and mobilizing social actors' network connections within and between organizations to gain access to other actors' resources" (Knoke, 1999, p. 17) deserve close study in understanding the strategic networks' configuration formations and dynamics. Finally as Baraldi (2008, p. 99) has emphasized, in organizational networks, "Network strategies cannot be used as shortcuts to compensate for severe weaknesses, but instead 
can only be pursued by firms that possess adequate competences, external organizational interfaces, and network-oriented cultures."

Taking into account the adopted criteria for the SLR (see Table 1), the content analysis allowed us to extract main network variables/elements, as well as network strategies, out of the highly-cited literature. Therefore, the study results are presented in the following section.

\section{RESULTS}

Adopting the following search string:

("strategic network" OR "organizational network") AND (configuration* OR shape* OR type*) OR ("network strategy*) AND (element* OR variable* OR feature*) AND NOT ("internal network*" OR "strategic coalition*" OR "organizational relationship*")

and, according to the five phases of the SLR previously described in Table 1, the salient variables/elements of strategic networks, organizational networks, and network strategies were identified, allowing us to finally propose a taxonomy for various networks and their corresponding strategies. Table 7 summarized the main outputs of the literature review process, particularly referring to its derived concepts.

Then by fulfilling the generalization phase (the fifth and the last phase of the SLR in this study), we identified 7 different configurations and their dominant relevant strategies. For each configuration, salient features were presented, revealing the key relationships each network possesses.

Table 7. Literature review and its derived key concepts

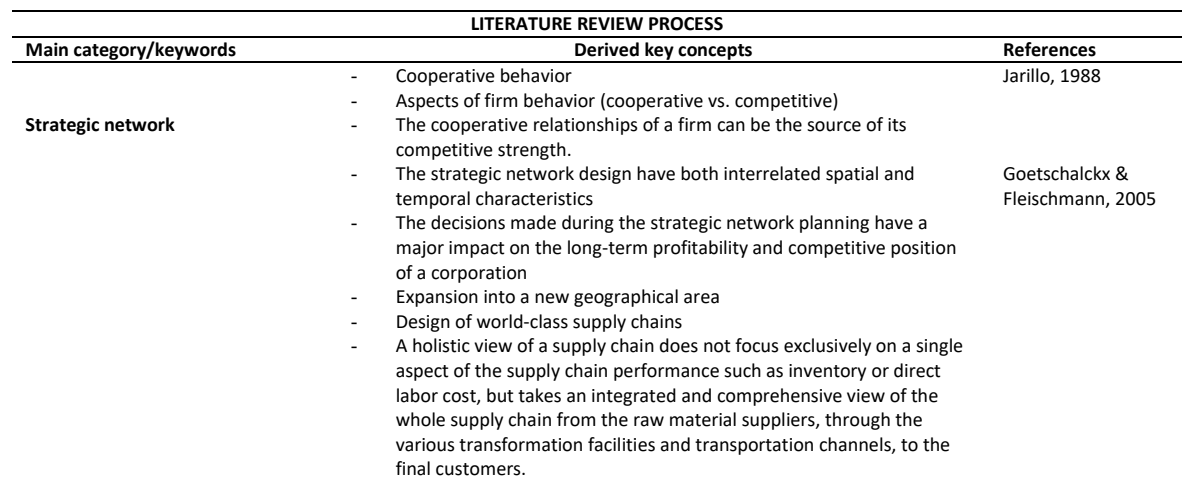




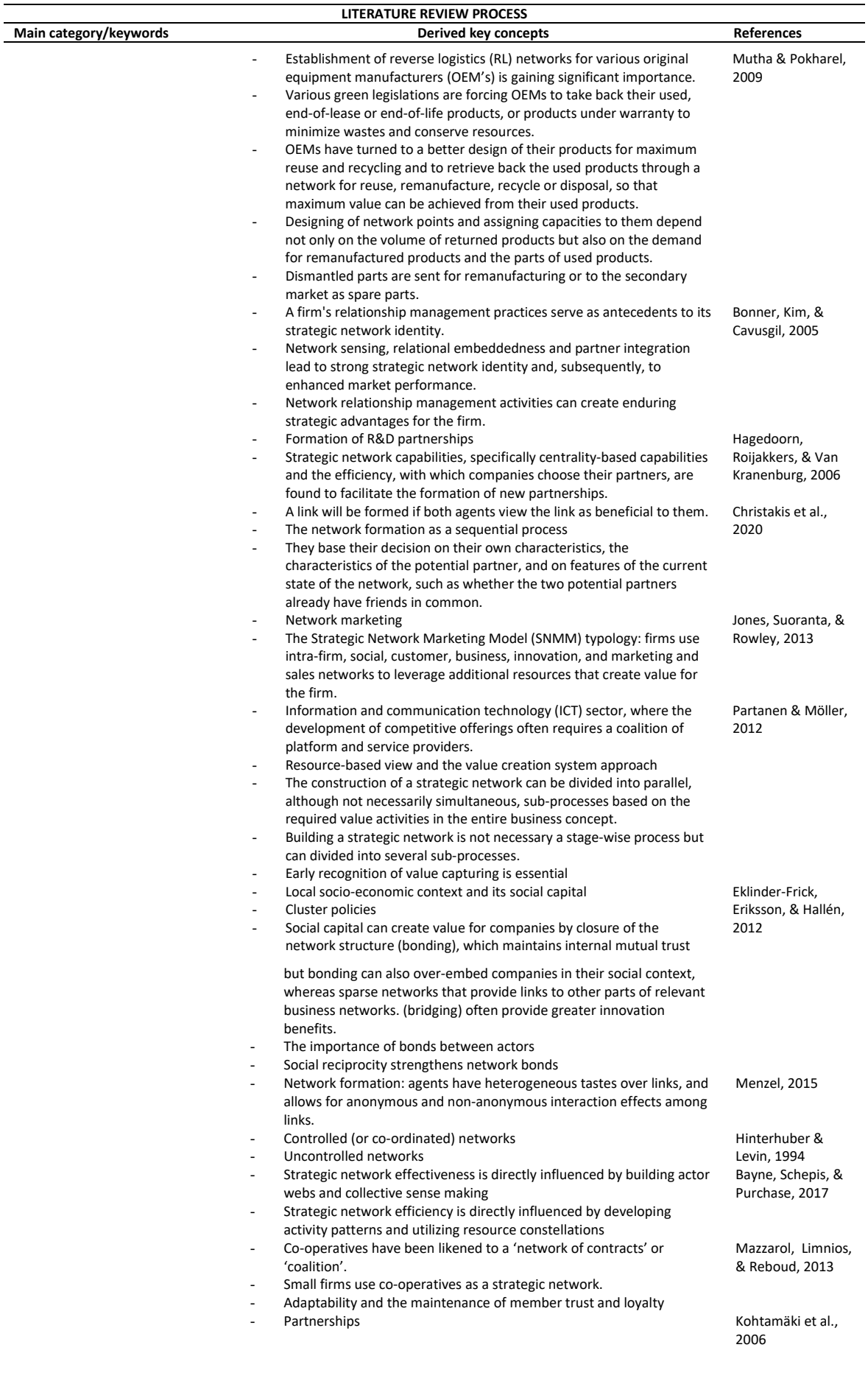




\begin{tabular}{|c|c|c|}
\hline \multicolumn{3}{|c|}{ LITERATURE REVIEW PROCESS } \\
\hline Main category/keywords & Derived key concepts & References \\
\hline & - $\quad$ Trust in network relations (Inter-organizational exchange) & Borch \& Arthur, \\
\hline & - $\quad$ Socio-economic relations of actors within strategic networks & 1995 \\
\hline & - $\quad$ Uni-entity networks vs. multi-entity networks & $\begin{array}{l}\text { Fernandes, Relvas, } \\
\text { \& Barbosa-Póvoa, } \\
2013\end{array}$ \\
\hline & $\begin{array}{l}\text { - Relational capabilities and cooperation, both of which affect a firm's } \\
\text { competitive position }\end{array}$ & Lorenzoni, 2010 \\
\hline & - Collaborative networks & Rui \& Bruyaka, \\
\hline & - $\quad$ Strategic nets of domestic and foreign partners & 2021 \\
\hline & $\begin{array}{l}\text { - Firms in government-supported strategic networks tend to rely on } \\
\text { professional network board members for support and assistance }\end{array}$ & $\begin{array}{l}\text { Thorgren, Wincent, } \\
\text { \& Anokhin, } 2010\end{array}$ \\
\hline & - $\quad$ Ties are not all the same and not all equally strategic & Hite, 2008 \\
\hline & - $\quad$ Multi-zone dispatching & Üster \& \\
\hline & & Maheshwari, 2007 \\
\hline & - $\quad$ Firm adaptations within strategic networks & Kohtamäki, \\
\hline & & Thorgren, \& \\
\hline & & Wincent, 2016 \\
\hline & - $\quad$ Formation of strategic networks under high uncertainty & $\begin{array}{l}\text { Jussila, Mainela, \& } \\
\text { Nätti, } 2016\end{array}$ \\
\hline & $\begin{array}{l}\text { - Close network relationships and interdependences of industrial } \\
\text { clusters have contributed significantly to the competitiveness of high- } \\
\text { technology clusters in the Asia-Pacific region. }\end{array}$ & $\begin{array}{l}\text { Niu, Miles, \& Lee, } \\
2008\end{array}$ \\
\hline & - $\quad$ Binary network marketing organizations & $\begin{array}{l}\text { Pedrood, Ahmadi, } \\
\& \text { Charafeddine, } \\
2008\end{array}$ \\
\hline \multirow[t]{7}{*}{ Organizational Network } & Inter-organizational network & $\begin{array}{l}\text { Ibarra, Kilduff, \& } \\
\text { Tsai, } 2005\end{array}$ \\
\hline & $\begin{array}{l}\text { - The two factors dynamically interact within inter-organizational } \\
\text { networks creating a cycle of improvement and contributing to the } \\
\text { development of innovation capacity for improved organizational } \\
\text { competitiveness. }\end{array}$ & Szeto, 2000 \\
\hline & - Co-innovation & Peters et al. 2010 \\
\hline & - $\quad$ Network structures & Knoben, \\
\hline & & Oerlemans, \& \\
\hline & & Rutten, 2006 \\
\hline & $\begin{array}{l}\text { - The inter-organizational network was valued by participants as a way } \\
\text { to share and transfer knowledge about better practice. }\end{array}$ & $\begin{array}{l}\text { Hartley \& Allison, } \\
2002\end{array}$ \\
\hline $\begin{array}{l}\text { Organizational network } \\
\text { configurations/shape }\end{array}$ & No relevant results found & - \\
\hline \multirow[t]{8}{*}{ Network Strategy } & $\begin{array}{l}\text { Supply network strategy (role and competence requirements): six } \\
\text { network management roles: network structuring agent; co-ordinator; } \\
\text { advisor; information broker; relationship broker; innovation sponsor. }\end{array}$ & $\begin{array}{l}\text { Harland \& Knight, } \\
2001\end{array}$ \\
\hline & - $\quad$ Social network marketing strategy & Nobre \& Silva, 2014 \\
\hline & - $\quad$ Supply network strategy & Yee \& Platts, 2006 \\
\hline & - $\quad$ Network R \&D Strategy & Håkansson \& \\
\hline & & Laage- \\
\hline & & Hellman,1984 \\
\hline & Cooperative strategy & Chang, Chiang, \& \\
\hline & & Pai, 2012 \\
\hline
\end{tabular}

Table 8 presented our results, summarized the network configurations, as well as their salient features, schematic figures, and their relevant dominant strategies. 
Table 8. Networks' taxonomy and their corresponding strategies

\begin{tabular}{|c|c|c|c|c|}
\hline \multicolumn{2}{|c|}{ Network configurations } & \multirow{2}{*}{$\begin{array}{l}\text { Salient features } \\
\text { Interdependence, } \\
\text { binary relationship }\end{array}$} & \multirow{2}{*}{ Schematic figures } & \multirow{2}{*}{$\begin{array}{l}\text { Relevant strategies } \\
\text { Multi-Level } \\
\text { Promotion Strategy }\end{array}$} \\
\hline A & $\begin{array}{l}\text { Reciprocally Interdependent } \\
\text { Networks }\end{array}$ & & & \\
\hline B & $\begin{array}{l}\text { Sequentially Interdependent } \\
\text { Networks }\end{array}$ & $\begin{array}{l}\text { Sequence, linearity, } \\
\text { interdependence }\end{array}$ & & $\begin{array}{l}\text { Just-In-Time } \\
\text { Strategy }\end{array}$ \\
\hline C & Partnering Networks & $\begin{array}{l}\text { Cooperation, } \\
\text { partners' networks }\end{array}$ & & $\begin{array}{l}\text { Network } \\
\text { Partnership } \\
\text { Strategy }\end{array}$ \\
\hline D & $\begin{array}{l}\text { Complementary } \\
\text { (Overlapping) Networks }\end{array}$ & $\begin{array}{l}\text { Partial relationship } \\
\text { in/for specific } \\
\text { intentions/activities }\end{array}$ & & $\begin{array}{l}\text { Compensatory } \\
\text { Strategy }\end{array}$ \\
\hline $\mathbf{E}$ & $\begin{array}{l}\text { Supporting (Logistic) } \\
\text { Networks }\end{array}$ & $\begin{array}{l}\text { Multiple entities } \\
\text { cooperation for } \\
\text { a single goal }\end{array}$ & & $\begin{array}{l}\text { Network Logistic } \\
\text { Strategy }\end{array}$ \\
\hline $\mathbf{F}$ & Distributing Networks & $\begin{array}{l}\text { Maximization of } \\
\text { the possibility of } \\
\text { distribution }\end{array}$ & & $\begin{array}{l}\text { Distributing } \\
\text { Network Strategy }\end{array}$ \\
\hline G & $\begin{array}{l}\text { Co-Innovation Knowledge- } \\
\text { Sharing Networks }\end{array}$ & $\begin{array}{l}\text { Innovation and } \\
\text { knowledge } \\
\text { synergism }\end{array}$ & & $\begin{array}{l}\text { Network R \& D } \\
\text { Strategy }\end{array}$ \\
\hline
\end{tabular}

The Reciprocally Interdependent Networks (Configuration A) is based on a binary relationship. This configuration is usually seen among MultiLevel Marketing (MLM), or network marketing/pyramidal selling. In this configuration, 'binary relationship' means each member of the network 
is only attached to another member that has chronologically joined the network sooner. The prevailing network strategy for this configuration is The Multi-Level Promotion Strategy, which is based on a convincing policy. In other words, the newcomers should be convinced that joining the network could be beneficial for them and their businesses.

The second derived configuration (The Sequentially Interdependent Networks-Configuration B) is usually witnessed in supply chain and production networks, where sequence, linearity, and interdependence usually prevail. In the sequentially interdependent networks, members should always be arranged in order of appearance; that means a specific place in the sequential chain network for each member (link) is always established and cannot be violated; otherwise, the configuration falls apart. The network usually gains its competitive advantage through The JIT Strategy; i.e. the materials and goods are strategically ordered, received, distributed, and stored, once it was the exact time for them. This strategy relies on a sophisticated and experienced strategic timing. In other words, the fittest strategic time for each of the JIT procedural entities; e.g. ordering, receiving, distributing, storing, etc.

The next derived configuration (C) is The Partnering Networks. Here, two or more partners join and form the network, and relate to the other partners, by means of cooperation. Partnering networks are likely to emerge in high-tech industries, in which organizations are used to cooperating for the production of sophisticated products. By this network, firms could compensate their strategic weaknesses by the strengths of the joined partner(s). In a more complicated and advanced formation of the partnering configuration, the cooperating entities could also make a close liaison with other networks' entities and expand the network into a humongous one. The corresponding core strategy in the Partnering Networks is the Network Partnership Strategy. The strategic efficiency and effectiveness of the participating network entities stem from strategic partnership and synergism. For example, one of the entities supplies spare parts, raw materials, or any other supporting backups, then the next entity in the partnering network manufactures, the other with efficient and superb distribution channels distributes, and so forth. Each entity shares its own competitive advantage(s) in the network and, hence, in the big picture they reach an insurmountable competitive synergism, since each entity has put forth and shared its best strategic part.

Furthermore, the Complementary (Overlapping) Networks (Configuration D) was derived through the SLR for partial relationships in/for specific intentions/activities and it is usually established among organizations aiming to complement some departments/units, without directly investing in their development. Thus, complementary networks allow partners to compensate each other's needs, weaknesses, and lack of technology, as well as to reach 
higher levels of efficiency, as this coexistence also helps organizational lives to be efficiently elongated.

On the other hand, when multiple entities cooperate to pursue a single goal, a Supporting (Logistic) Network emerges (Configuration E). The most frequent configuration of the logistic networks involves multiple supporting organizations linked to one leader company/organization (the target company/organization). Thus, in this configuration, we have supporting entities and the leading entity. The former are usually behind-the-scenes and the latter presents the network façade. In the Network Logistic Strategy, the prevalent strategy of such networks, the target company selects and arranges a network of supporting/logistic companies to be able to reach its strategic organizational goals, such as the increase in production, or upgrading the quality of its manufactured goods.

Maximizing the chance and scale of distribution is usually the final aim of many distributing networks, inspired via an exclusive distribution philosophy. In these networks, there is a core company that promotes its distribution policy via a dominant strategy, the Distributing Network Strategy, in other words, under this strategy, the core company does its best to expand the network until it reaches its full potential hence maturity; (i.e., until it was not possible to be expanded or further expansion jeopardizes the efficiency and effectiveness of the core company). A Distributing Network (F) forms around the core company and attaches as many distributing channels as possible to the so-called core company.

Finally, Configuration G, or the Co-Innovation Knowledge-Sharing Network emerges once the collaboration among the partners aims to foster knowledge sharing and innovation synergism, thus supporting the efficacy of both the actors and the system/network. That is, the innovative companies join a network for the dissemination, promotion, and partial or complete sharing of emerging knowledge. In such circumstances, the Network R\&D Strategies could dominate the network, allowing organizations to share their scientific research, support each other, and create new outputs due to their co-innovation. Silicon Valley, in the southern part of the San Francisco Bay Area in Northern California, as the global center for high technology and innovation, is a good example of such Co-Innovation Knowledge-Sharing Networks. What made the difference? According to sociologist Annalee Saxenian (1996), a major factor was the development of a "collective learning" environment in Silicon Valley in which fierce industrial competitors agreed to collaborate and share basic technical knowledge for the benefit of all. 


\section{DISCUSSION AND CONCLUSION}

As shown by this paper, there is a large array of different ways to define inter-organizational networks and their role in formal organizational settings. The huge amount of available studies and perspectives about the topic fostered confusion and fragmentation, hindering a greater understanding and coherence of the field. The mentioned lack of clarity grows even more when referring to network strategies (Wheelwright \& Hayes, 1985), network strategies extending strategic frameworks to larger and more complex network systems in terms of competitive priorities, structure and infrastructure (Harland et al., 1999, Brun \& Castelli, 2008). Harland and Knight (2001) assumed that companies may be able to manage networks in which they operate and that it is therefore important to understand and develop an appropriate network strategy. In line with the mentioned, many authors (Kathuria, 2000, Zhao et al., 2006, Miller \& Roth, 1994) emphasize the need to investigate firms' strategies through the use of configurations (Kathuria, 2000, Zhao et al., 2006, Miller \& Roth, 1994). However, the development of configurations in the field of network strategy seems to be a still unexplored field (Macchion et al., 2015; Vereecke \& Van Dierdonck, 2002; Bozarth \& McDermott, 1998). As a consequence, this paper aimed to fill the existing gap, by providing a new and valuable framework to classify inter-organizational networks and their corresponding strategies.

In line with the above, an SLR - including literature acquisition, compilation, filtration, extraction and finally generalization - was managed, resulting in a literature-supported taxonomy of both inter-organizational networks and network strategies. Particularly, Scopus and WoS were referred in order to collect data and refine them in accordance with each database's functionalities. Next, a wide thematic analysis was employed to derive and form seven strategic network configurations and then to introduce and define their corresponding preponderant network strategies. The authors named these networks as Reciprocally Interdependent Networks, Sequentially Interdependent Networks, Partnering Networks, Complementary (Overlapping) Networks, Supporting (Logistic) Networks, Distributing Networks, and Co-Innovation Knowledge-Sharing Networks. Besides, their corresponding network strategies were identified as Multi-Level Promotion Strategy, Just-In-Time Strategy, Network Partnership Strategy, Compensatory Strategy, Network Logistic Strategy, Distributing Network Strategy, and Network R\&D Strategy, respectively.

The theoretical contribution of this study is its presentation of the taxonomy of networks and network strategies in strategic management as a pioneering work. Since existing taxonomies were mainly developed for 
production and supply network configurations (Macchion et al., 2015), as well as for specific industries - electronic, machinery, and electrical sectors (Caniato et al., 2009, Brun \& Castelli, 2008, Luzzini \& Ronchi, 2010) - this is the first research attempting to extend the focus of the analysis to the whole range of networks.

The strength of the study is its reliance on the two major scientific databases of Scopus and WoS, which include some of the best-published papers on network studies. Moreover, the introduced network taxonomy and its related network strategies present a literature-supported systematics or a system of classification for the strategic studies of networks.

Future research that includes more databases could build upon this study by extending its positive features/classes and compensate for its potential shortages. Moreover, the study's implications for research and practice are, first, the classification and labeling of prevalent networks (taxonomy), which provides future researchers with a referential network system with its pertinent strategies in the strategic studies and, second, this classification system could facilitate the teaching and learning of network strategic issues in the academic atmosphere.

We think that this perspective of the study is particularly interesting and can contribute to advancing the research stream on network strategies by providing a complete understanding of the phenomenon within different industries.

\section{References}

Bakkalbasi, N., Bauer, K., Glover, J., \& Wang, L. (2006). Three options for citation tracking: Google Scholar, Scopus and Web of Science. Biomedical Digital Libraries, 3(1), 1-8. https://doi.org/10.1186/1742-5581-3-7

Baraldi, E. (2008). Strategy in industrial networks: Experiences from IKEA. California Management Review, 50(4), 99-126. https://doi. org/10.2307/41166458

Bayne, L., Schepis, D., \& Purchase, S. (2017). A framework for understanding strategic network performance: Exploring efficiency and effectiveness at the network level. Industrial Marketing Management, 67, 134-147. https://doi.org/10.1016/j.indmarman.2017.07.015

Berry, J., Hart, W. E., Phillips, C. A., \& Uber, J. (2004). A general integerprogramming-based framework for sensor placement in municipal water networks. In Critical Transitions in Water and Environmental Resources Management (pp. 1-10). Salt Lake City, Utah: ASCE. https:// doi.org/10.1061/40737(2004)455

Biemans, W. G. (1991). User and third-party involvement in developing medical equipment innovations. Technovation, 11(3), 163-182. https:// doi.org/10.1016/0166-4972(91)90032-Y 
Blanco, I., Lowndes, V., \& Pratchett, L. (2011). Policy networks and governance networks: Towards greater conceptual clarity. Political Studies Review, 9(3), 297-308. https://doi.org/10.1111/j.1478-9302.2011.00239.x

Bonner, J. M., Kim, D., \& Cavusgil, S. T. (2005). Self-perceived strategic network identity and its effects on market performance in alliance relationships. Journal of Business Research, 58(10), 1371-1380. https:// doi.org/10.1016/j.jbusres.2004.07.002

Borch, O. J., \& Arthur, M. B. (1995). Strategic networks among small firms: Implications for strategy research methodology. Journal of Management Studies, 32(4), 419-441. https://doi.org/10.1111/j.1467-6486.1995. tb00783.x

Börzel, T. A. (1998). Organizing Babylon: On the different conceptions of policy networks. Public Administration, 76(2), 253-273. https://doi. org/10.1111/1467-9299.00100

Bozarth, C., \& McDermott, C. (1998). Configurations in manufacturing strategy: A review and directions for future research. Journal of Operations Management, 16(4), 427-439. https://doi.org/10.1016/ S0272-6963(98)00022-9

Brun, A., \& Castelli, C. (2008). Supply chain strategy in the fashion industry: Developing a portfolio model depending on product, retail channel and brand. International Journal of Production Economics, 116(2), 169-181. https://doi.org/10.1016/j.ijpe.2008.09.011

Burnham, J. F. (2006). Scopus database: A review. Biomedical Digital Libraries, 3(1), 1-8. https://doi.org/10.1186/1742-5581-3-1

Canestrino, R., \& Magliocca, P. (2019). Dal knowledge management ai knowledge ecosystem. Napoli: Collana del Dipartimento di Economia dell'Università degli Studi di Foggia.

Caniato, F., Caridi, M., Castelli, C., \& Golini, R. (2011). Supply chain management in the luxury industry: A first classification of companies and their strategies. International Journal of Production Economics, 133(2), 622-633. https://doi.org/10.1016/j.ijpe.2011.04.030

Carmichael, S. G. (2016). The flash report: The global digital economy. Harvard Business Review (April 29). Retrieved from https://hbr.org/2016/04/theflash-report-the-global-digital-economy

Chang, C. W., Chiang, D. M., \& Pai, F. Y. (2012). Cooperative strategy in supply chain networks. Industrial Marketing Management, 41(7), 1114-1124. https://doi.org/10.1016/j.indmarman.2012.04.011

Christakis, N., Fowler, J., Imbens, G. W., \& Kalyanaraman, K. (2020). An empirical model for strategic network formation. In The Econometric Analysis of Network Data (pp. 123-148). Cambridge, MA: Academic Press. https://doi.org/10.1016/B978-0-12-811771-2.00012-2

Crawford Jr, J. W., \& Krahn, S. L. (1998). The demanding customer and the hollow organization: Meeting today's contract management challenge. Public Productivity \& Management Review, 22(1), 107-118. https://doi. org/10.2307/3380593 
Dal Molin, M., \& Masella, C. (2016). Networks in policy, management and governance: A comparative literature review to stimulate future research avenues. Journal of Management \& Governance, 20(4), 823-849. https:// doi.org/10.1007/s10997-015-9329-x

De La-Torre-Ugarte-Guanilo, M. C., Takahashi, R. F., \& Bertolozzi, M. R. (2011). Revisión sistemática: Nociones generales. Revista da Escola de Enfermagem da USP, 45(5), 1255-1261.

Denyer, D., \& Tranfield, D. (2009). Producing a systematic review. In D. A. Buchanan \& A. Bryman (Eds.), The Sage Handbook of Organizational Research Methods (pp. 671-689). Thousand Oaks, California: Sage Publications Ltd.

Dess, G. G., Lumpkin, G. T., Eisner, A. B., \& McNamara, G. (2006). Strategic Management: Text and Cases. Pennsylvania: McGraw-Hill/Irwin.

Ebers, M., \& Jarillo, J. C. (1997). Preface: The construction, forms, and consequences of industry networks. InternationalStudies of Management \& Organization, 27(4), 3-21. https://doi.org/10.1080/00208825.1997.11 656716

Eklinder-Frick, J., Eriksson, L. T., \& Hallén, L. (2011). Bridging and bonding forms of social capital in a regional strategic network. Industrial Marketing Management, 40(6), 994-1003. https://doi.org/10.1016/j. indmarman.2011.06.040

Eklinder-Frick, J., Eriksson, L. T., \& Hallén, L. (2012). Effects of social capital on processes in a regional strategic network. Industrial Marketing Management, 41(5), 800-806. https://doi.org/10.1016/j. indmarman.2012.06.007

Fernandes, L. J., Relvas, S., \& Barbosa-Póvoa, A. P. (2013). Strategic network design of downstream petroleum supply chains: Single versus multientity participation. Chemical Engineering Research and Design, 91(8), 1557-1587. https://doi.org/10.1016/j.cherd.2013.05.028

Forouharfar, A., Rowshan, S. A., \& Salarzehi, H. (2019). Social entrepreneurship strategic grid: Visualizing classification, orientation and dimensionality in the strategic paradigms of governmental-scale social entrepreneurship (A literature-based approach). Cogent Business \& Management, 6(1), 1644714. https://doi.org/10.1080/23311975.2019.1644714

Goetschalckx, M., \& Fleischmann, B. (2005) Strategic network planning. In H. Stadtler \& C. Kilger (Eds.), Supply Chain Management and Advanced Planning. Springer, Berlin, Heidelberg. https://doi.org/10.1007/3-54024814-5_7

Hagedoorn, J., Roijakkers, N., \& Van Kranenburg, H. (2006). Inter-firm R\&D networks: The importance of strategic network capabilities for high-tech partnership formation. British Journal of Management, 17(1), 39-53. https://doi.org/10.1111/j.1467-8551.2005.00474.x

Håkansson, H., \& Waluszewski, D., (2007), Knowledge and Innovation in Business and Industry: The Importance of Using Others (Vol. 5). Londra, UK: Routledge 
Håkansson, H., \& Laage-Hellman, J. (1984). Developing a network R\&D strategy. Journal of Product Innovation Management: An International Publication of the Product Development \& Management Association, 1(4), 224-237. https://doi.org/10.1111/1540-5885.140224

Harland, C. M., \& Knight, L. A. (2001). Supply network strategy: Role and competence requirements. International Journal of Operations \& Production Management, 21(4), 476-489. https://doi. org/10.1108/01443570110381381

Harland, C. M., Lamming, R. C., \& Cousins, P. D. (1999). Developing the concept of supply strategy. International Journal of Operations \& Production Management, 19(7), 650-674. https://doi. org/10.1108/01443579910278910

Hartley, J., \& Allison, M. (2002). Good, better, best? Inter-organizational learning in a network of local authorities. Public Management Review, 4(1), 101-118. https://doi.org/10.1080/14616670110117332

Hill, C. (2002). Network Literature Review: Conceptualizing and Evaluating Networks. MA: Calgary Health Region.

Hinterhuber, H. H., \& Levin, B. M. (1994). Strategic networks - The organization of the future. Long Range Planning, 27(3), 43-53. https:// doi.org/10.1016/0024-6301(94)90189-9

Hite, J. M. (2008). The role of dyadic multi-dimensionality in the evolution of strategic network ties. In J. A. C. Baum \& T. J. Rowley (Eds.), Network Strategy (Advances in Strategic Management, Vol. 25 (pp. 133-170). Bingley: Emerald Group Publishing Limited. https://doi.org/10.1016/ S0742-3322(08)25004-7

Ibarra, H., Kilduff, M., \& Tsai, W. (2005). Zooming in and out: Connecting individuals and collectivities at the frontiers of organizational network research. Organization Science, 16(4), 359-371. https://doi.org/10.1287/ orsc.1050.0129

Isett, K. R., Mergel, I. A., LeRoux, K., Mischen, P. A., \& Rethemeyer, R. K. (2011). Networks in public administration scholarship: Understanding where we are and where we need to go. Journal of Public Administration Research and Theory, 21(suppl_1), i157-i173. https://doi.org/10.1093/ jopart/muq061

Jarillo, J. C. (1988). On strategic networks. Strategic Management Journal, 9(1), 31-41. https://doi.org/10.1002/smj.4250090104

Jarillo, J. C. (1993). Strategic Networks: Creating the Borderless Organisation. Oxford, UK: Butterworth-Heine Mgmt.

Jia, F., \& Jiang, Y. (2018). Sustainable global sourcing: A systematic literature review and bibliometric analysis. Sustainability, 10(3), 595. https://doi. org $/ 10.3390 /$ su10030595

Jones, R., Suoranta, M., \& Rowley, J. (2013). Strategic network marketing in technology SMEs. Journal of Marketing Management, 29(5-6), 671-697. https://doi.org/10.1080/0267257X.2013.797920 
Jussila, A., Mainela, T., \& Nätti, S. (2016). Formation of strategic networks under high uncertainty of a megaproject. Journal of Business \& Industrial Marketing, 31(5), 575-586. https://doi.org/10.1108/JBIM-03-2014-0055

Kale, P., Singh, H., \& Perlmutter, H. (2000). Learning and protection of proprietary assets in strategic alliances: Building relational capital. Strategic Management Journal, 21(3), 217-237. https://doi.org/10.1002/ (SICI)1097-0266(200003)21:3<217::AID-SMJ95>3.0.CO;2-Y

Kathuria, R. (2000). Competitive priorities and managerial performance: A taxonomy of small manufacturers. Journal of Operations Management, 18(6), 627-641. https://doi.org/10.1016/S0272-6963(00)00042-5

Kitchenham, B. A., \& Charters, S. (2007). Guidelines for performing systematic literature reviews in software engineering. Keele University and Durham University Joint Report. Retrieved from http://www.cs.ecu. edu/gudivada/research/papers/guidelines-for-se-literature-reviewssummary.pdf

Knoben, J., Oerlemans, L. A., \& Rutten, R. P. (2006). Radical changes in interorganizational network structures: The longitudinal gap. Technological Forecasting and Social Change, 73(4), 390-404. https://doi.org/10.1016/j. techfore.2005.05.010

Knoke, D. (1999). Organizational networks and corporate social capital. In Corporate Social Capital and Liability (pp. 17-42). Boston, MA: Springer. https://doi.org/10.1007/978-1-4615-5027-3_2

Kohtamäki, M., Thorgren, S., \& Wincent, J. (2016). Organizational identity and behaviors in strategic networks. Journal of Business \& Industrial Marketing, 31(1), 36-46. https://doi.org/10.1108/JBIM-07-2014-0141

Kohtamäki, M., Vesalainen, J., Varamäki, E., \& Vuorinen, T. (2006). The governance of partnershipsandastrategicnetwork.ManagementDecision, 44(8), 1031-1051. https://doi.org/10.1108/00251740610690603

Krzakiewicz, K., \& Cyfert, S. (2013). The network concept of strategic management and its limitations. Management, 17(1), 19-30.

Kuntz, L., \& Vera, A. (2007). Modular organization and hospital performance. Health Services Management Research, 20(1), 48-58. https://doi. org/10.1258/095148407779614990

LaGuardia, C. (2005). Scopus vs. Web of Science. Library Journal, 130, 40-42. Li, J., Burnham, J. F., Lemley, T., \& Britton, R. M. (2010). Citation analysis: Comparison of Web of Science ${ }^{\circledR}$, Scopus $^{\mathrm{TM}}$, SciFinder ${ }^{\circledR}$, and Google Scholar. Journal of Electronic Resources in Medical Libraries, 7(3), 196217. https://doi.org/10.1080/15424065.2010.505518

Lin, H. M., Lin, C. P., \& Huang, H. C. (2011). Embedding strategic alliances in networks to govern transaction hazards: Evidence from an emerging economy. Asian Business \& Management, 10(2), 183-208. https://doi. org/10.1057/abm.2010.8

Liu, T., \& Tang, L. (2020). Open innovation from the perspective of network embedding: Knowledge evolution and development trend. 
Scientometrics, 124, 1053-1080. https://doi.org/10.1007/s11192-02003520-7

Lorenzoni, G. (2010). Genesis of a research field: District, network, strategic network. Journal of Management \& Governance, 14(3), 221-239. https:// doi.org/10.1007/s10997-010-9151-4

Luzzini, D., \& Ronchi, S. (2010). Purchasing management in the luxury industry: Organization and practices. Operations Management Research, 3(1), 7-21. https://doi.org/10.1007/s12063-010-0042-2

Macchion, L., Moretto, A., Caniato, F., Caridi, M., Danese, P., \& Vinelli, A. (2015). Production and supply network strategies within the fashion industry. International Journal of Production Economics, 163, 173-188. https://doi.org/10.1016/j.ijpe.2014.09.006

Mazzarol, T., Limnios, E. M., \& Reboud, S. (2013). Co-operatives as a strategic network of small firms: Case studies from Australian and French cooperatives. Journal of Co-operative Organization and Management, 1(1), 27-40. https://doi.org/10.1016/j.jcom.2013.06.004

Mclntyre, D. P., \& Srinivasan, A. (2017). Networks, platforms, and strategy: Emerging views and next steps. Strategic Management Journal, 38(1), 141-160. https://doi.org/10.1002/smj.2596

Menzel, K. (2015). Strategic network formation with many agents. Working papers, NYU. Retrieved from https://economics.sas.upenn.edu/sites/ default/files/filevault/event_papers/network_formation.pdf

Merli, R., Preziosi, M., \& Acampora, A. (2018). How do scholars approach the circular economy? A systematic literature review. Journal of Cleaner Production, 178, 703-722. https://doi.org/10.1016/j.jclepro.2017.12.112

Miller, J. G., \& Roth, A. V. (1994). A taxonomy of manufacturing strategies. Management Science, 40(3), 285-304. https://doi.org/10.1287/ mnsc.40.3.285

Mitchell, G. E. (2014). Strategic responses to resource dependence among transnational NGOs registered in the United States. Voluntas: International Journal of Voluntary and Nonprofit Organizations, 25(1), 67-91. https://doi.org/10.1007/s11266-012-9329-2

Mizruchi, M. S., \& Galaskiewicz, J. (1993). Networks of interorganizational relations. Sociological Methods \& Research, 22(1), 46-70. https://doi. org/10.1177/0049124193022001003

Mutha, A., \& Pokharel, S. (2009). Strategic network design for reverse logistics and remanufacturing using new and old product modules. Computers \& Industrial Engineering, 56(1), 334-346. https://doi.org/10.1016/j. cie.2008.06.006

Narasimhan A., Yu H. H. (2021). Organizational design: Inviting the outside in. Retrieved from https://www.imd.org/research-knowledge/articles/ organizational-design-inviting-the-outside-in/

Niu, K. H., Miles, G., \& Lee, C. S. (2008). Strategic development of network clusters: A study of high technology regional development and global 
competitiveness. Competitiveness Review: An International Business Journal. 18(3), 176-191. https://doi.org/10.1108/10595420810905966

Nobre, H., \& Silva, D. (2014). Social network marketing strategy and SME strategy benefits. Journal of Transnational Management, 19(2), 138-151. https://doi.org/10.1080/15475778.2014.904658

Oliver, A. L., \& Ebers, M. (1998). Networking network studies: An analysis of conceptual configurations in the study of inter-organizational relationships. Organization Studies, 19(4), 549-583. https://doi. org/10.1177/017084069801900402

Orzes, G., Moretto, A. M., Ebrahimpour, M., Sartor, M., Moro, M., \& Rossi, M. (2018). United Nations Global Compact: Literature review and theorybased research agenda. Journal of Cleaner Production, 177, 633-654. https://doi.org/10.1016/j.jclepro.2017.12.230

Partanen, J., \& Möller, K. (2012). How to build a strategic network: A practitioner-oriented process model for the ICT sector. Industrial Marketing Management, 41(3), 481-494. https://doi.org/10.1016/j. indmarman.2011.05.002

Pedrood, N., Ahmadi, H., \& Charafeddine, H. A. (2008). Systematic profitability analysis of binary network marketing organizations. Direct Marketing: An International Journal, 2(2), 81-96. https://doi. org/10.1108/17505930810881743

Peters, L. D., Pressey, A. D., Westerlund, M., \& Rajala, R. (2010). Learning and innovation in inter-organizational network collaboration. Journal of Business \& Industrial Marketing, 25(6), 435-442. https://doi. org/10.1108/08858621011066026

Powell, W. W., Koput, K. W., \& Smith-Doerr, L. (1996). Inter-organizational collaboration and the locus of innovation: Networks of learning in biotechnology. Administrative Science Quarterly, 41(1), 116-145. https:// doi.org/10.2307/2393988

Rampersad, G., Quester P., \& Troshani I., (2010). Managing innovation networks: Exploratory evidence from ICT, biotechnology and nanotechnology networks. Industrial Marketing Management, 39(5), 793-805. https://doi.org/10.1016/j.indmarman.2009.07.002

Rey-Martí, A., Ribeiro-Soriano, D., \& Palacios-Marqués, D. (2016). A bibliometric analysis of social entrepreneurship. Journal of Business Research, 69(5), 1651-1655. https://doi.org/10.1016/j.jbusres.2015.10.033

Rui, H., \& Bruyaka, O. (2021). Strategic network orchestration in emerging markets: China's catch-up in the high-speed train industry. British Journal of Management, 32(1), 7-19. https://doi.org/10.1111/1467-8551.12457

Satell, G. (2015). What makes an organization "Networked"? Harvard Business Review. Retrieved from https://hbr.org/2015/06/what-makesan-organization-networked

Saxenian, A. (1996). Regional Advantage: Culture and Competition in Silicon Valley and Route 128. Cambridge, MA: Harvard University Press. 
Siva, V., Gremyr, I., Bergquist, B., Garvare, R., Zobel, T., \& Isaksson, R. (2016). The support of Quality Management to sustainable development: A literature review. Journal of Cleaner Production, 138, 148-157. https:// doi.org/10.1016/j.jclepro.2016.01.020

Snyder, H., Witell, L., Gustafsson, A., Fombelle, P., \& Kristensson, P. (2016). Identifying categories of service innovation: $A$ review and synthesis of the literature. Journal of Business Research, 69(7), 2401-2408. https:// doi.org/10.1016/j.jbusres.2016.01.009

Sydow, J. (1998). Franchise systems as strategic networks: Studying network leadership in the service sector. Asia Pacific Journal of Marketing and Logistics, 10, 108-120. https://www.wiwiss.fu-berlin.de/fachbereich/ bwl/management/sydow/media/pdf/Sydow__1998____franchise_ systems_as_strategic_networks.pdf

Szeto, E. (2000). Innovation capacity: Working towards a mechanism for improving innovation within an inter-organizational network. The TQM Magazine, 12(2),149-158. https://doi.org/10.1108/09544780010318415

Thorgren, S., Wincent, J., \& Anokhin, S. (2010). The importance of compensating strategic network board members for network performance: A contingency approach. British Journal of Management, 21(1), 131-151. https://doi.org/10.1111/j.1467-8551.2009.00674.x

Tranfield, D., Denyer, D., \& Smart, P. (2003). Towards a methodology for developing evidence-informed management knowledge by means of systematic review. British Journal of Management, 14(3), 207-222. https://doi.org/10.1111/1467-8551.00375

Unterkalmsteiner, M., Gorschek, T., Islam, A. K. M. M., Chow Kian Cheng, Permadi, R. B., \& Feldt, R. (2012). Evaluation and measurement of software process improvement-A Systematic Literature Review. IEEE Transactions on Software Engineering, 38(2), 398-424. https://doi. org/10.1109/TSE.2011.26

Üster, H., \& Maheshwari, N. (2007). Strategic network design for multizone truckload shipments. IIE Transactions, 39(2), 177-189. https://doi. org/10.1080/07408170600735504

Vega-Redondo, F. (2013). Network organizations. Journal of Complex Networks, 1(1), 72-82. https://doi.org/10.1093/comnet/cnt002

Vereecke, A., \& Van Dierdonck, R. (2002). The strategic role of the plant: Testing Ferdows's model. International Journal of Operations \& Production Management, 22(5), 492-514. https://doi. org/10.1108/01443570210425147

Vigolo, V., Sallaku, R., \& Testa, F. (2018). Drivers and barriers to clean cooking: A systematic literature review from a consumer behavior perspective. Sustainability, 10(11), 4322. https://doi.org/10.3390/su10114322

Wheelwright, S. C., \& Hayes, R. H. (1985). Competing Through Manufacturing (pp. 99-109). Cambridge, MA: Harvard Business Review Case Services. 
Yee, C. L., \& Platts, K. W. (2006). A framework and tool for supply network strategy operationalisation. International Journal of Production Economics, 104(1), 230-248. https://doi.org/10.1016/j.ijpe.2005.06.002

Zhao, X., Sum, C. C., Qi, Y., Zhang, H., \& Lee, T. S. (2006). A taxonomy of manufacturing strategies in China. Journal of Operations Management, 24(5), 621-636. https://doi.org/10.1016/j.jom.2005.07.003

\begin{abstract}
Abstrakt
CEL: Celem niniejszego artykułu jest wprowadzenie ogólnej, wszechstronnej taksonomii sieci i jej odpowiednich strategii w celu ułatwienia nauczania i uczenia się strategicznych koncepcji sieci w zarzqdzaniu strategicznym. METODYKA: Aby spełnić swój zamiar, w artykule przyjęto systematyczny przeglqd literatury (SLR), gdyż wprowadzona taksonomia i odpowiadajqce jej strategie powinny być komplementarnym odzwierciedleniem i podsumowaniem aktualnej literatury dotyczqcej badań nad sieciami strategicznymi. WYNIKI: W pracy przedstawiono siedem potencjalnych konfiguracji sieci, a następnie przystapiono do zaproponowania ich odpowiednich strategii w odniesieniu do relacji i form sieci. Wyróżniono sieci wzajemnie współzależne, sieci sekwencyjnie współzależne, sieci partnerskie, sieci komplementarne (nakładajqce się), sieci wspierajqce (logistyczne), sieci dystrybucyjne oraz sieci wspótinnowacji i dzielenia się wiedzq. Odpowiadajqce im strategie sieciowe zostały zidentyfikowane odpowiednio jako wielopoziomowa strategia promocji, strategia just-in-time, strategia partnerstwa sieci, strategia kompensacyjna, strategia logistyczna sieci, strategia sieci dystrybucyjnej oraz strategia sieci badawczo-rozwojowej. IMPLIKACJE DLA TEORII I PRAKTYKI: Systematyka lub system klasyfikacji jest fundamentalnq koniecznościq w każdej dziedzinie wiedzy, z której korzystajq zarówno środowiska akademickie, jak i osoby uczqce się. W zwiqzku z tym, artykuł ten dostarcza wyczerpujqcych, ale zwięzłych sposobów klasyfikacji sieci i ich strategii w nadziei na przezwyciężenie niedostatku wciq̨ż istniejqcego w literaturze. Wysiłki te zachęcajq do przyszłych badań i rozmów na temat sieci i strategii sieciowych, proponujq̨c ramy przewodnie dla debaty. ORYGINALNOŚĆ I WARTOŚĆ: Brak konsensusu co do teorii i konceptualizacji w badaniach sieci strategicznych stał się inspiracja dla tych badań, co pozwoliło na wyjaśnienie wspomnianego istniejqcego niedostatku.
\end{abstract}

Słowa kluczowe: taksonomia sieci, konfiguracja sieci, strategia sieci, zarzqdzanie strategiczne, systematyczny przegląd literatury (SLR)

\title{
Biographical notes
}

Rossella Canestrino, Ph.D., is Assistant Professor at 'Parthenope' University of Naples, Italy, where she teaches Business Ethics and CSR and Digital Marketing. She has also been Visiting Professor at University of Jaèn, (Spain), from 2018/2019 to 2019/2020. Rossella Canestrino is coordinator of the scientific project 'Teaching Digital Entrepreneurship' (TED), financed under the Erasmus+ programme (KA203), and she is involved in several international research collaborations. Particularly, her research topics mainly belong to 
Knowledge Management, Social Innovation, and Business Ethics. Among the underlined research fields, her research activity focuses on the way an ethical climate, and different values and beliefs, may affect firms' propensity to engage in entrepreneurial activities and adopt socially responsible practices. She is a member of EBEN (European Business Ethics Network) and Associate Editor for the Journal of Sustainable Entrepreneurship and Corporate Social Responsibility. Rossella Canestrino is a reviewer for several high-ranked journals, such as The Journal of Business Ethics, The TQM Journal, and The Journal of Knowledge Management.

Amir Forouharfar received his Bachelor's degree in English Language and Literature from Arak University. He graduated as an honor student with a Master's degree in Entrepreneurship Management and a Ph.D. in Public Administration from the University of Sistan and Baluchestan. His main areas of research are entrepreneurship, organization theory, public administration, and philosophy. His key areas of expertise include strategic entrepreneurship, organization theory development, and philosophical epistemology. Dr. Forouharfar has published in fully refereed prestigious journals, conferences, and books. He has extensively published with Emerald, Edward Elgar, Springer, and Taylor \& Francis. He has co-edited several book titles on strategic entrepreneurship as well as COVID-19 repercussions with Springer.

\section{Conflicts of interest}

The authors declare no conflict of interest.

\section{Citation}

Canestrino, R., \& Forouharfar, A. (2021). Networks and network strategies: New theorization based upon a systematic literature review. Journal of Entrepreneurship, Management and Innovation, 17(3), 37-66. https://doi. org/10.7341/20211732 